\title{
5軸制御マシニングセンタの傾斜回転軸位置決め 精度測定方法の開発
}

\author{
ーロータリエンコーダと水準器を使った傾斜計の開発一
}

\author{
崔 成日** 高橋和也 ${ }^{* *}$ 堤 正臣 $^{* * *}$ 佐藤隆太*** \\ Development of Measuring Method for Positioning Accuracy of Tilting \\ Axes in Five-axis Machining Centers \\ - Development of Clinometer using a Rotary Encoder and a Level -
}

Chengri CUI, Kazuya TAKAHASHI , Masaomi TSUTSUMI and Ryuta SATO

\begin{abstract}
This paper describes the measuring methods for positioning accuracy of tilting axes in five-axis controlled machining centers with a tilting rotary table. The top surface of the tilting rotary table is generally in higher position than the tilting axis. In this case, there is no measuring method except for a manually operated clinometer. Thus, a clinometer consisting of a precision rotary encoder and a bubble level was firstly developed. In the method, operators have to read visually the scale of the level and the reading accuracy is dependent on their ability. Instead of the bubble level, an electronic level with high resolution was employed for comparison. A ball bar equipment was also applied to measure the angular positioning accuracy of the tilting rotary table, as the ball bar equipment can measure the angular displacement continuously.
\end{abstract}

Key words: five-axis, machining center, positioning accuracy, tilting axis, clinometer, rotary encoder, ball bar

\section{1. 緒}

近年, 複雑形状部品の加工や加工効率の向上のために，5 軸 制御マシニングセンタが利用されるようになってきた. 5 軸制 御マシニングセンタは, 工作物と工具との間の相対姿勢を任意 に変えられる特徵があり, 複雑形状部品の加工や加工効率の向 上が期待できる機械である. しかし，5軸制御マシニングセン タは従来の 3 軸制御マシニングセンタに比べて, 機構が複雑で, 多くの誤差成分があることが指摘されており, 精度の補正が重 要な課題になっている ${ }^{1 \sim 3)}$.

マシニングセンタの精度検査項目の一つである軸の位置決 め精度測定方法に着目すると, 5 軸制御マシニングセンタの直

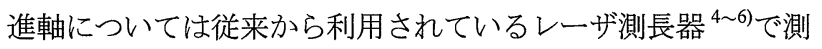
定でき, 旋回軸についても図 1 に示したレーザ干渉計と割出し 盤とを組み合わせた装置で測定することができる7).

しかし図 2 に示した傾斜回転テーブルのように回転軸(A'軸) がテーブル上面よりも低い場合があるように, 割出し盤の中心 を傾斜軸の回転中心に合わせられない場合は, この測定装置を 用いることはできない. また，このような測定装置で測定する ときに, 測定間隔は割出し盤の割出し角度に依存するために, より小さな割出し角度で測定を行うことは困難である.

テーブル上面が傾斜軸中心線よりも高い位置にある場合で もテーブル上に載せるだけで傾斜面の角度を測定する装置と して, 従来から傾斜計 (クリノメータ)8) が利用されてきたが, その傾斜計は接眼レンズを覗き込んで目盛を合わせて読み取 る方式のために, 今ではほとんど利用されていないようである.

* 原稿受付 平成 19 年 2 月 23 日

** 学生会員 東京農工大学大学院（東京都小金井市中町 2-24-16)

*** 正 会 員 東京農工大学大学院共生科学技術研究院

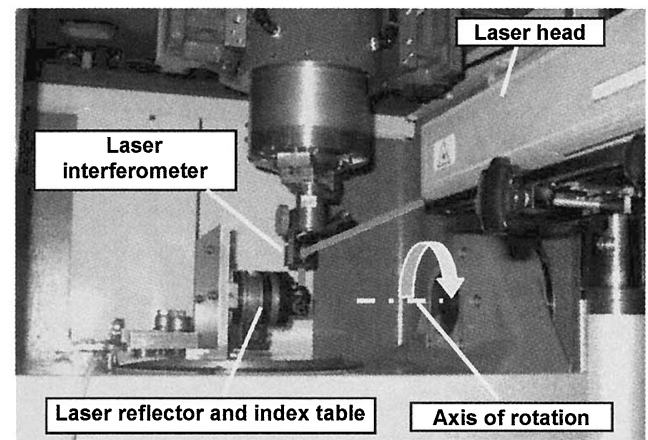

Fig. 1 Conventional measurement method by means of laser interferometer and precision index table.

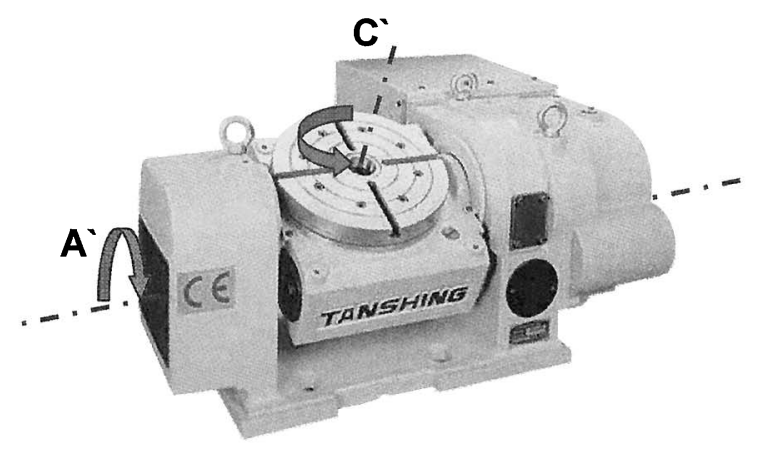

Fig. 2 Tilting rotary table

そこで本研究では, 適当な装置のない 5 軸制御マシニングン 夕傾斜回転軸の位置決め精度測定装置の開発に取り組んだ. 具 体的には, 高精度のロータリエンコーダで回転角度を読み取る ために, 気泡管式水準器によって重力方向を検出し, その問題 点を明らかにする．次いでボールバーによる測定を行い，考案 
した方法で高精度に測定できることを明らかにする，その後， 測定の自動化のために電子水準器をセンサとする方式につい て検討し，その問題点を明らかにする.

\section{2. 傾斜計の權成と測定原理}

試作した傾斜計を傾斜回転テーブルに取り付けた様子を図 3 に示す.この傾斜計はロータリエンコーダ（仕様は, 衰 1 参照) と振り子とから構成されている. この装置の原理は, 傾斜軸が 回転したときにロータリエンコーダの回転軸に取り付けられ た振り子が重力によって回転して, 鉛直方向を向いたときの角 度をロータリエンコーダで読み取る方式である.

ロータリエンコーダの回転軸には摩擦トルクが作用するた めに，例えば，振り子を動かす振幅や速度によって，振り子の 静止する位置が一定にはならず, 鉛直方向に対して傾いたまま で止まる. そこで, その位置を常に一定にするために, 振り子 の上に水準器を取り付けることにした.

気泡管式水準器を取り付けた場合は, 各測定位置において振 り子を手で微調整して水準器の気泡が常に一定の目盛で一致 するようにして読みをとった。一方, 電子水準器を取り付けた 場合は, 振子が止まって安定したところで，ロータリエンコー ダと電子水準器との読みを記録して, 電子水準器の読みとの差 を算出して傾斜軸（以下 A'軸という）の回転角度を求めた。

なお, この傾斜計と同様の測定器がすでに発明されている ${ }^{9}$. その装置は手動で調整を行ってロータリエンコーダで角度を 読む方式である.

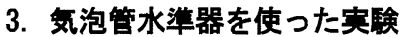

\section{1 实験方法}

傾斜軸の位置決め精度測定は, 次の手順によって行った.

(1)テーブル上面を水平にした状態で試作した測定装置をテー ブル上に取り付け, 気泡管式水準器の目盛が読みやすくなる ように振り子を適当に微動させ, 目盛に合わせる. その角度 位置を, 傾斜軸の $0^{\circ}$ の位置とし, ロータリエンコーダの原 点とする.

(2)次の目標値に傾斜軸を回転させて位置決めする.

(3)(1)で, 読みとった目盛に気泡が合うように振り子の傾き角を 微調整する.

(4)そのときのロータリエンコーダの読みを記録する.

(5)その次からは, (2)から(4)の操作を繰り返し, 最終の目標位置 まで位置決めを行う。

\section{2 实験結果及び考察}

\section{2 .1 傾斜計の繰り返し性}

図 3 に示すようにして $\mathrm{A}^{\prime}$ 軸を測定対象として目標角度位置 を 0 と $10^{\circ}$ とし, それぞれ位置決めを 25 回行った.このとき， 位置決めは $0^{\circ}$ から $10^{\circ}$ に位置決めしたときの読みを $10^{\circ}$ の位置 での読みとし, $10^{\circ}$ から $0^{\circ}$ に位置決めしたときの読みを $0^{\circ} の$ 位 置決めの值として, 目標位置と実際の位置との差を測定値とし た.

位置決めの回数と偏差との関係を図 4(a)に示す. 図によると 測定回数が増えるにつれて偏差が大きくなっていき，18 回を 超えた辺りからほぼ一定值になっている.これには, 様々な要 因が考えられる. 水準器の目盛を常に一定の位置で読むことに 徐々に慣れが現れていること, 位置決めを繰り返して行ってい るために発熱によって傾斜軸の傾き角が徐々に大きくなり, 18 回を超えたところで熱的に平衡状態になったことなどが理由

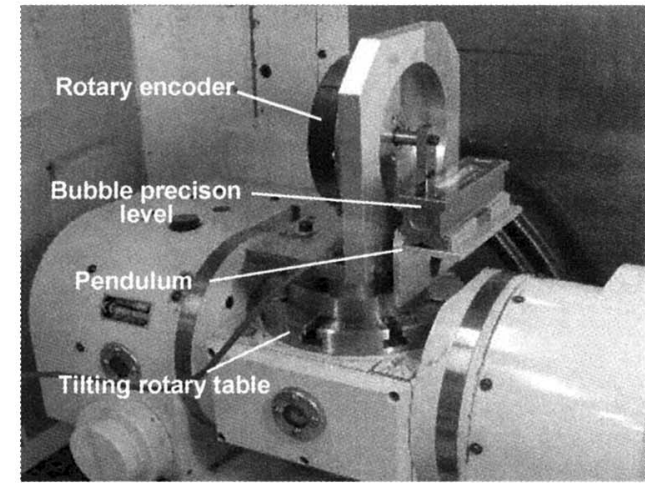

Fig. 3 Clinometer mounted on the tilting rotary table of five-axis machining center

Table 1 Specifications of rotary encoder

\begin{tabular}{l|c}
\hline Type & Incremental \\
\hline Resolution & 0.36 arcsec \\
\hline System accuracy & \pm 2 arcsec \\
\hline Repeatability & \pm 0.18 arcsec \\
\hline
\end{tabular}

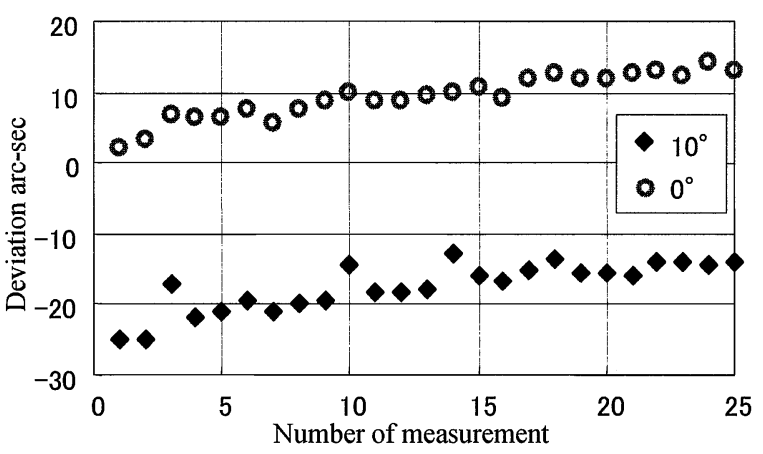

(a) Positioning deviationzs

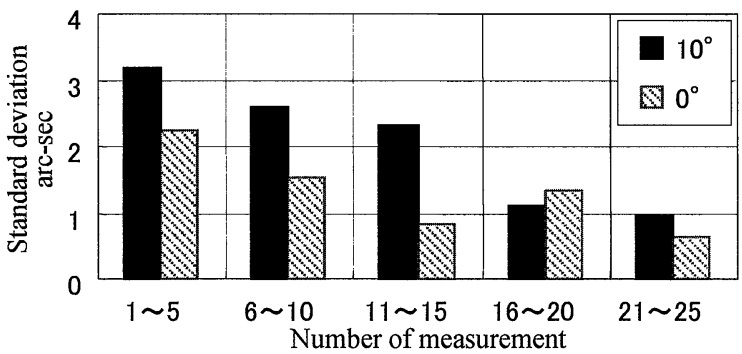

(b) Standard deviations

Fig. 4 Relationship between the number of measurements and the standard deviations

として考えられる. なお,この測定には約 4 時間を要している. 測定值のばらつきを 5 回ごとの標準偏差に計算すると, 図 4(b)に示すように測定回数が増えるにつれて標準偏差が小さ くなっていくことがわかる. 測定開始時と終了時の室温の変化 も空調していることから小さく, 発熱による変化と考えるより も, 目盛を合わせて振り子を微動させる操作に習熟してきた結 果, 測定值のばらつきが小さくなったと考えたほうが妥当であ る.

3.2 .2 位置決め測定例 1

$\mathrm{A}^{\prime}$ 軸の測定範囲を 0 90。とし, 目標位置の間隔を $5^{\circ}$ として 測定を行ったときの位置と偏差との関係を図 5 に示す．なお, 


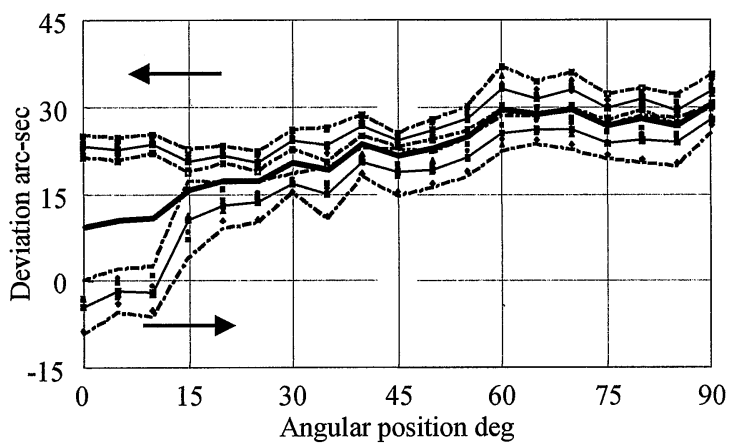

(a) Positioning deviations

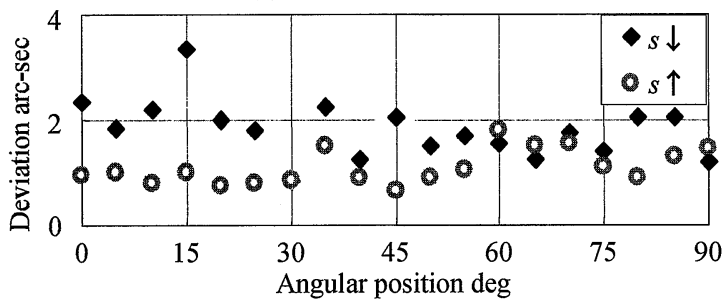

(b) Standard deviations

Fig. 5 Angular positioning deviations of the A'-axis and the standard deviations

データの整理方法及び記号は，ISO 230-2 に準拠した. 図によ ると，往路と復路とには差があるが，15゚までの変化とそれを

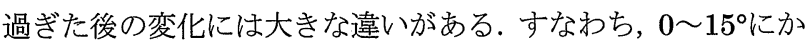
けて往路 $(\rightarrow)$ と復路 $($ )で差が大きく, 20 90では差が小さく なっていることがわかる．特に往路の $10^{\circ}$ と $15^{\circ}$ との間の変化 が大きいことがわかる。

通常, 往路と復路との差は, 反転值として ISO230-2 では定 義されているが, 多くの場合この值は, バックラッシとみなさ れる. この反転值は, モータの回転角度とテーブルの回転角度 との差であり,この間にある機構のバックラッシ及び弾性変形 が原因であると考えられる.

位置決め精度試験を行う場合にはレーザ干渉計を設置する 程度で特に測定器の自重やモーメントを考える必要がなかっ た. しかし, 本研究で対象とする傾斜テーブルの場合には測定 器によるモーメントが測定に及ぼす影響を無視できない可能 性がある. とくに使用する測定器の質量が大きく, 開発した傾 斜計の場合に, 傾斜角度が 90 のときモーメントが約 $22.4 \mathrm{Nm}$ にもなることから，その影響があると思われる。

図 5 に示した $10^{\circ}$ から $15^{\circ}$ に回転するときに偏差が急激に大 きくなるのは, この角度位置付近で傾斜計の自重によるトルク が傾斜軸系の摩擦トルクを超え, バックラッシなどの影響によ って急激に変化したものと考えられる. 図 5(b)に示す標準偏差 の值も $15^{\circ}$ の位置で大きくなっており, 摩擦に基づく不確か な要因が大きくなっているものと考えられる.

\section{2 .3 位置決め測定例 2}

次に，スタンドアローンタイプの CNC 円テーブルを測定対 象として位置決め偏差の測定を行った。この CNC 円テーブル は, 円テーブルの反対側に傾斜計に使われているものと同じ仕 様のロータリエンコーダが取り付けられており, 円テーブルの 回転角度をフィードバックできるようになっている. 絶対位置 決め精度も高く，仕様書では土2”となっている.

この CNC 円テーブルを用いて測定範囲を-90〜90，測定 間隔を $30^{\circ}$ こて位置決め偏差の測定を行った. この測定と同 時に CNC 円テーブルのロータリエンコーダの值も読み取り， 傾斜計で測定した偏差との比較も行った.

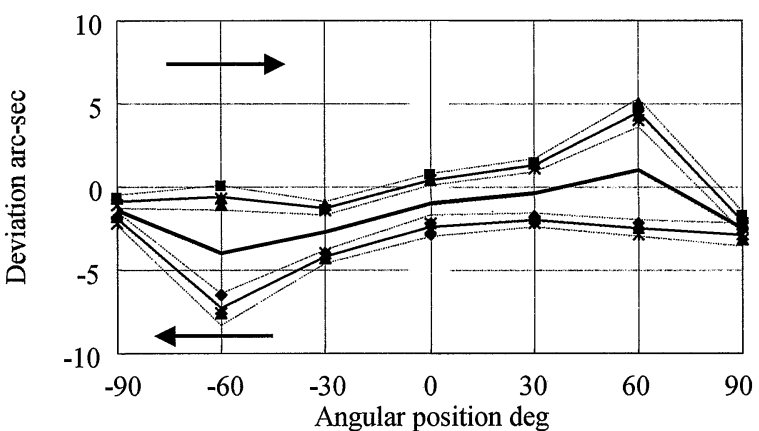

(a) Positioning deviations

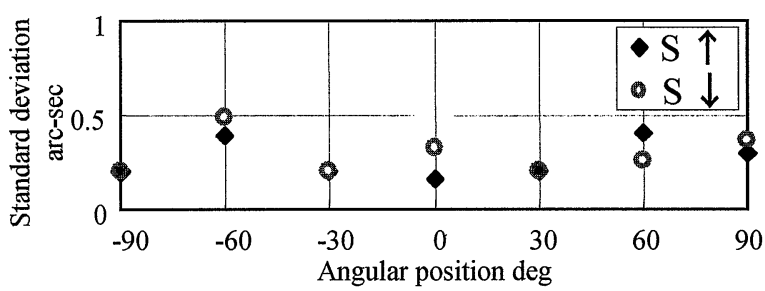

(b) Standard deviations

Fig. 6 Angular positioning deviations measured by the developed clinometer

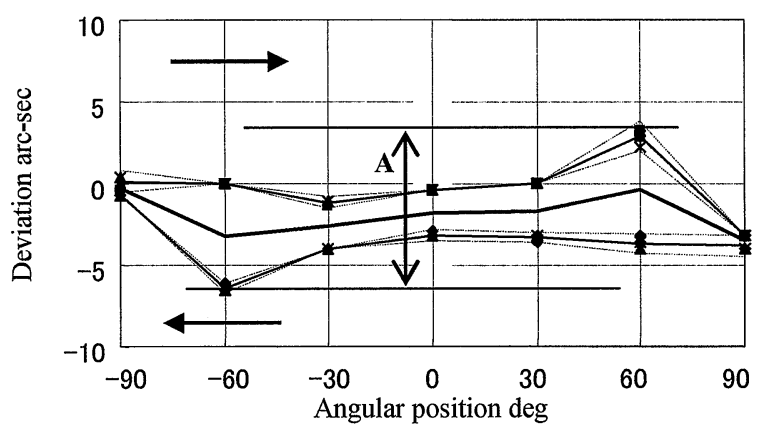

(a) Positioning deviations

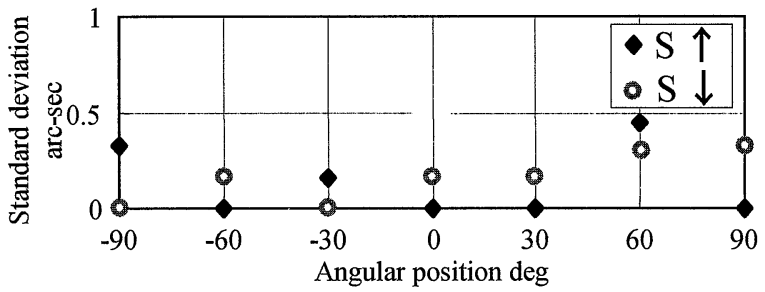

(b) Standard deviations

Fig. 7 Angular positioning deviations measured by the rotary encoder for feedback

図 6 に傾斜計による位置決め偏差曲線を, 図 7 に指令角度と CNC 円テーブルのロータリエンコーダから読み取った角度と の差を示す. 図 6 と図 7 とを比較すると, 全体的な傾向は両方 とも良く一致している.最も大きく異なるところでもその差が 約 2 ”程度であり，仕様書上のロータリエンコーダのシステム 精度と同程度である.また, この測定結果から測定対象の $\mathrm{CNC}$ 円テーブルの両方向位置決めの正確さA とがわかる。

図 6(b) と図 7(b) とから CNC 円テーブルの繰返し性と傾斜計 の標準偏差は両方とも $0.5 ”$ 以下であり傾斜計の方が若干大き い. それは傾斜計の方の標準偏差は CNC 円テーブル自体の繰 返し性も含んでいるためである。

以上の結果から試作した装置の 5 回測定分の標準偏差は 0.5”よりも小さいく測定できているといえる.

測定例 1 に比べ標準偏差が小さくなったのは測定を複数回 
繰り返すことによって振子を調整し気泡を目盛に合わせる技 術が向上したこと, 測定対象自体の繰返し精度の差, また, 測 定例 2 の場合は測定の目標点が少ないために測定に約 3 時間か かったのに対して, 測定例 1 の場合は目標点の数が多く, 約 7 時間かかったため, 測定者の疲れもあり, ばらつきが大きくな ったことが原因として考えられる. 以上から, 傾斜軸の位置決 め精度は, 気泡管式水準器を用いて, かなり高精度で測定でき ることがわかった. そこで, この測定方法が他の測定方法と比 ベて同等かどうかを検討するために, ボールバーによる測定結 果と比較することにした.

\section{4. ボールパーによる測定結果との比較}

本研究の測定対象である傾斜回転テーブルにおいて傾斜軸 (A'軸) のウォームホイールの歯数は 72 あるので，50で 1 周 期分のピッチ誤差が出ると考えられる. そこで, 試作した装置 でそのピッチ誤差が測定できるかを確かめるために傾斜回転 テーブルの $\mathrm{A}^{\prime}$ 軸において測定範囲を $0 \sim 10^{\circ}$, 目標位置の間隔 を $0.5^{\circ} と し て$ 測定を行い, ボールバーで測定した結果と比較し た.

ここでボールバーとは伸縮機構をもつバーの両端に鋼球を 取り付け, 永久磁石が内蔵されたソケットが鋼球を支える機構 であり, 両端鋼球間の相対距離を内蔵した変位計によって検出 する測定器である.

\section{1 ボールバーによる測定方法}

図 8 に示したように, ボールバーをテーブル上面に平行にな るように取り付け，この平行な状態を常に保つように $\mathrm{Y}, \mathrm{Z}$, $\mathrm{A}^{\prime}$ 軸を同期させ, ボールバーの伸縮量から $\mathrm{A}^{\prime}$ 軸の回転角度の 誤差を求めた. この測定方法では, ウオームギアのかみ合い誤 差が測定されることはすでに分かっている ${ }^{10)}$. しかし，この場 合には直進軸の真直度, 直角度などの幾何学的な偏差や機械座 標系に対する A 軸の位置偏差の影響が測定結果に含まれるが, ここではそれら誤差を無視して傾斜計で測定した位置決め偏 差とボールバーで測定した值とを比べることにした.

ここで, 実験条件を同じにするためにボールバーで測定を行 うときには，A'軸に傾斜計と同程度のモーメントがかかるよう に錘を付けて測定を行った.

\section{2 实験結果の比較}

図 9 に測定結果を示す. 図示した結果の実線はボールバーに よる測定結果, 記号 $(\boldsymbol{\square}, \boldsymbol{\Delta})$ で示す点は, 傾斜計による測定 結果を示す. また, ボールバーで測定したデータの往路のデー 夕と傾斜計で測定した往路のデータのそれぞれ $0 \circ$ の位置にお ける偏差，つまり測定開始点の偏差を 0”として表示した.

図からボールバーによる測定曲線は, 傾斜計で測定の結果と 往路・復路ともによく一致していることがわかる.

さらに, ウオームギアの歯数の影響（ $5^{\circ}$ 周期）だけでなく, それよりも小さな周期の偏差までも測定できているのがわか る. 傾斜計による測定では, $0.5^{\circ}$ 刻みに測定しているので, 細 かい周期までは判別できないが，それ以外のところは，ボール バーの結果とよく一致している.したがって, 開発した方法は, ボールバーと同程度に測定できているといえる.

そこで, 測定範囲を $90^{\circ}$, 測定間隔を 50 として傾斜計による 測定結果とボールバーによる測定結果との比較を図 10 に示す. 図には $A^{\prime}$ 軸が $90^{\circ}$ に回転したときのモーメント，つまり，A' 軸にかかる最大モーメントが傾斜計を付けた場合と同程度の 約 $22.4 \mathrm{Nm}$ になるように錘をつけて実験を行ったボールバー

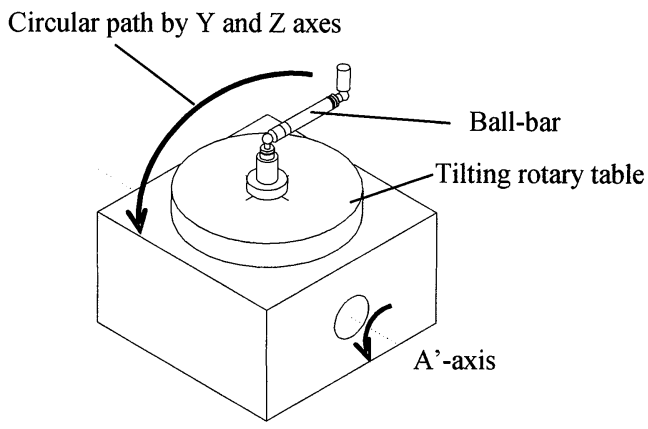

Fig. 8 Measurement of simultaneous three axis control movement with ball bar

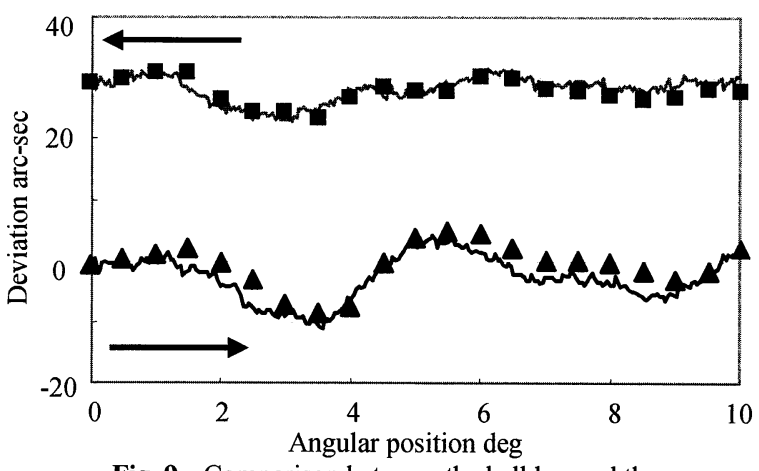

Fig. 9 Comparison between the ball bar and the developed clinometer

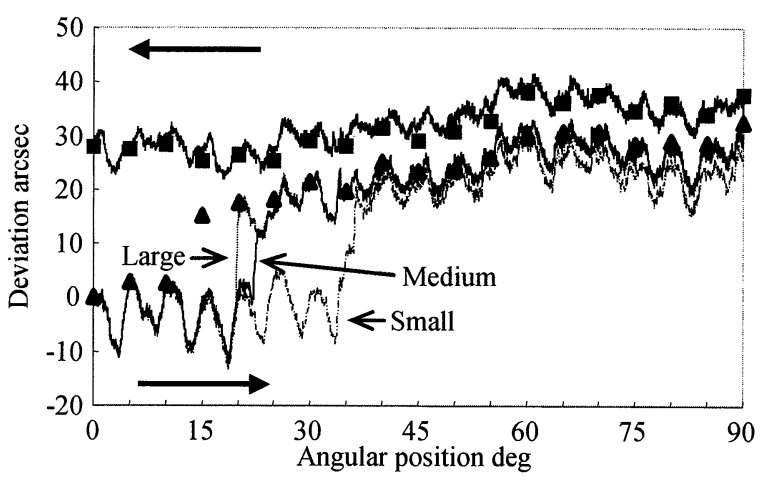

Fig. 10 Comparison between ball bar and clinometer

の往路と復路(Medium)の測定結果, さらに約 $24.2 \mathrm{Nm}$ (Large) と約 $16.3 \mathrm{Nm}$ (Small)のモーメントがかかるように錘を変えて 実験を行った往路の測定結果を示す. 傾斜計とボールバーの結 果を比較すると測定の復路については結果が良く一致するが, 往路については測定結果に 3.3.1 で述ベたバックラッシの影響 による位置決め誤差の急激な変化が現れる位置が異なってお り，傾斜計の方が早く現れている．その原因としてボールバー で測定を行う場合には傾斜軸連続的に回転させているのに対 して傾斜計で測定を行う場合は 5 こごとに傾斜軸を停止させて いるためにトルクの影響が現れたと考えられる.これを確認す るために 3 種類の錘を付けて行ったボールバーの測定結果か らも回転軸にかかるモーメントが小さいほど位置決め偏差が 急激に変化する角度位置が大きくなっていることがわかる.

\section{5. 電子水準器を使った実験}

ロータリエンコーダと気泡管式水準器を用いた傾斜計では, 1”以下の精度で測定できることがわかったが, 測定に熟練度が 必要なこと, 及び測定者の疲れによって測定結果にばらつきが 
Table 2 Specifications of electronic inclinometer used

\begin{tabular}{l|l}
\hline Full output & $\pm 5.7 \mathrm{deg}$ \\
\hline Resolution & $0.1 \mathrm{arcsec}$ \\
\hline Maximum Linearity & $0.05 \% \mathrm{FS}( \pm 20.7 \mathrm{arcsec})$ \\
\hline Repeatability & $0.001 \% \mathrm{FS}( \pm 0.414 \mathrm{arcsec})$ \\
\hline Frequency response $(-3 \mathrm{db})$ & $5.0 \mathrm{~Hz}$ \\
\hline
\end{tabular}

生じてしまうことなどの問題点がある. また，ロータリエンコ 一ダの值はパソコンに取り込めるが, 各測定位置において手作 業で気泡が一定の目盛に合うように振り子を調整する必要が あるために, また傾斜するテーブルの上に載せるだけで測定で きるものではなく，測定時間も長いなどの問題点もある.

これらの問題点を解決するために気泡管式水準器の代わり に電子水準器を使うことにした. 電子水準器は傾き角度をパソ コンに記録できるために振子を調整する必要なく, 振子が鉛直 方向に対して傾いた角度を記録して, ロータリエンコーダの回 転角度と引算することで傾斜軸の位置決め精度を測定するこ とができる.

表 2 に本研究で使用した電子水準器の仕様を示す. 本研究で 用いた電子水準器は高分解能, 高繰り返し性をも持っているが 直線性が悪く $0.05 \% \mathrm{FS}$ ( $\pm 20.7 ”)$ となっている. そのために 引算により回転軸の回転角度を求めるとき, 電子水準器の直線 性を調心゙, 場合によってはその非線形成分を補正する必要があ る.

\section{1 事水準器の直線性}

\subsection{1 実験方法}

傾斜テーブルに傾斜計を取り付け, 傾斜テーブルを回転させ ず振子を $-5 \sim+5^{\circ}$ の範囲で $0.5^{\circ} こ ゙ と$ 回転させる. このときロー タリエンコーダの精度が比較的に高いのでその読みを正しい ものとして電子水準器の傾き角度 $\theta$ とロータリエンコーダの 回転角度を比較することで電子水準器の直線性を調べること ができる. 一方で, 電子水準器は電気的ノイズが大きいので電 子水準器の出力をローパスフィルタに通すことにし, さらに各 測定位置において 1000 個のデータをサンプリングし, 平均値 を求めた.

\section{1 .2 実験結果}

図 11 に 5 回測定分の結果を示す.グラフは横軸にロータリ ンエンコーダの回転角度, つまり電子水準器が傾いた実際の角 度, 縦軸に電子水準器の角度センサーが検出した傾き角度から ロータリエンコーダの回転角度を引いた值, つまり, 電子水準 器が検出した傾き角度と実際の傾き角度との差を示す. 図によ ると電子水準器が正又は負の方向に傾いて行くと実際の傾き 角度と電子水準器が検出した傾斜角度との差が 2 次曲線に従 う傾向がある. 各測定位置での 5 回測定分の標準偏差は 1 ”以 下であった. そこで各測定位置において 5 回分の測定データを 平均して得られたグラフから近似曲線を求めた結果, 式(1)の ように近似曲線として表すことができた.

$$
f(\theta)=0.00005\left(\theta^{2}+\theta+0.4\right)
$$

ここで $\theta$ は電子水準器の傾き角度である.

式(1)から使用した電子水準器の傾き角度が-2〜1間であれば 測定結果に非線形性の影響はあまり含まれないが, $-2 \sim 1^{\circ}$ の範 囲以外にあった場合は式(1)を用いて非線形成分を補正す

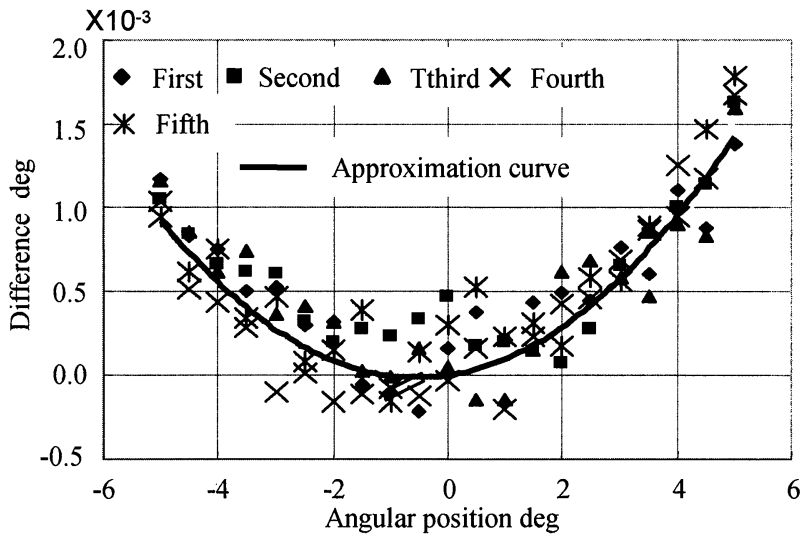

Fig. 11 Nonlinearity of electronic a level

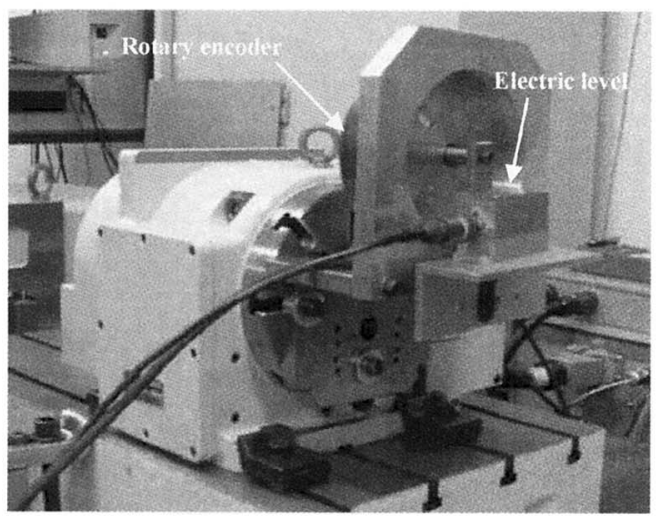

Fig. 12 Measurement by means of in electric level on a standalone $\mathrm{CNC}$ rotary table

る必要がある。

\section{2 電子水準器による位置決め偏差}

5.2.1 測定対象及び測定方法

図 12 に示したように CNC 円テーブルに傾斜計を取り付け, 測定範囲を-90〜 $+90^{\circ}$ ，間隔を $30^{\circ}$ として位置決め精度測定を 行った.

測定手順を以下に示す.

(1) 円テーブルを $0^{\circ}$ に設定し, 電子水準器の值が $0 \mathrm{~V}$ に近い值 になるように人手で振子を調整し, ロータリエンコーダの 值を 0 に設定する. 次に電子水準器の值（初期値）を記 録しておく.

(2) 円テーブルを測定開始点に位置決めする.

(3) 振子が安定して止まっているところの電子水準器及びエ ンコーダの出力をパソコンに記録する.このとき振子が鉛 直方向に対して大きく傾いていれば振子を-2〜10範囲内 に入るように振子を調整する。

(4) 次の目標值に円テーブルを位置決めし, (3)の操作を行う.

(5)次からは(2)(3)の操作を繰り返し, 最終の目標位置まで位置 決めを行い, データを記録する

(6) 各測定位置で記録した電子水準器の值から(1)で記録した 初期值を引く.

\section{2 .2 実験結果及び考察}

図 13(a)，(b)に電子水準器による位置決め偏差の測定曲線と 標準偏差，図 14(a)，(b)に CNC 円テーブルのロータリエンコ 一ダから読み取った值から求めた偏差と標準偏差を示す. 実験 を行う前に振子に重りを付けて，振子が-2 $1^{\circ}$ の範囲内になる ように重りの位置を調整した. 


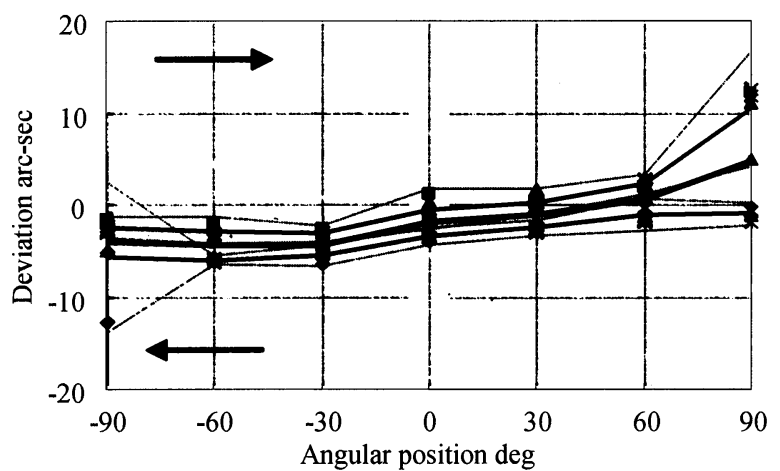

(a) Positioning deviations

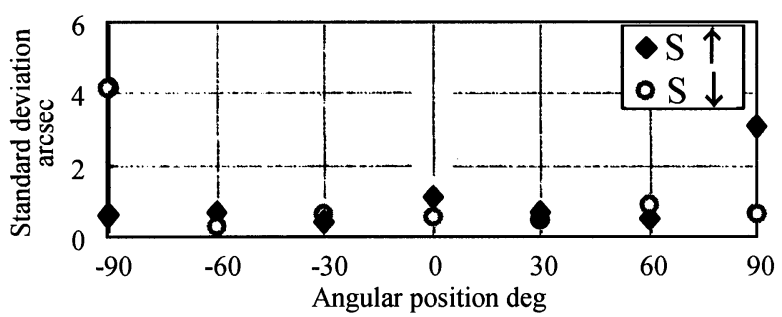

(b) Standard deviations

Fig. 13 Angular positioning deviations measured by the developed clinometer

図 13(a) と図 14(a)とを比較すると位置決め偏差曲線は全体 的に CNC 円テーブル側のロータリエンコーダの結果は-60〜 $+60^{\circ}$ までにはほぼ水平な直線状になっているのに対して傾斜 計の結果では土方向で誤差が大きくなっている. しかし, その 差はわずか 2 3"程度でありロータリエンコーダのシステム精 度と同程度である.

以上の結果からロータリエンコーダと電子水準器を併用す ることによって振り子を調整する必要なく, 5 回測定分の標準 偏差が 1 ”以下で位置決め精度を測定することができたと言え る. しかし, 回転軸に 1"の角度誤差があった場合, 回転中心 から $200 \mathrm{~mm}$ 離れた点について約 $1 \mu \mathrm{m}$ の位置誤差を起すこと から傾斜回転軸の位置決め精度を評価, 補正し, 直進軸と同程 度の精度に向上させるためには傾斜計の精度を 1 ”よりも高い 精度にする必要があると言える. そのためには本研究で用いた 電子水準器よりも高性能な重力方向を検出するためのセンサ が必要となる. なお, 測定にかかる時間については気泡管式水 準器を使った場合に比べ約 1 時間と 2 時間も短くなった.

\section{6. 結}

傾斜回転軸の位置決め精度測定方法としてロータリエンコ ーダと水準器とを使った傾斜計を試作して測定実験を行い, 以 下のような結果がえられた.

1) ロータリエンコーダと気泡管式水準器とを使った傾斜計 の場合には, 5 回測定分の標準偏差が 0.5 ”以下の高い精度 で測定でき, ウオームギアの噛み合い誤差の変化もボール バーと同程度に検出することができる. しかし，この測定 方法は，手作業で振子を調整するため，測定時間が長く， 測定の熟練度や疲労によって結果にばらつきが生じる.

2 ）ロータリエンコーダと電子水準器とを使った傾斜計の場 合には，ほとんど振子を調整する必要なく，5回測定分の

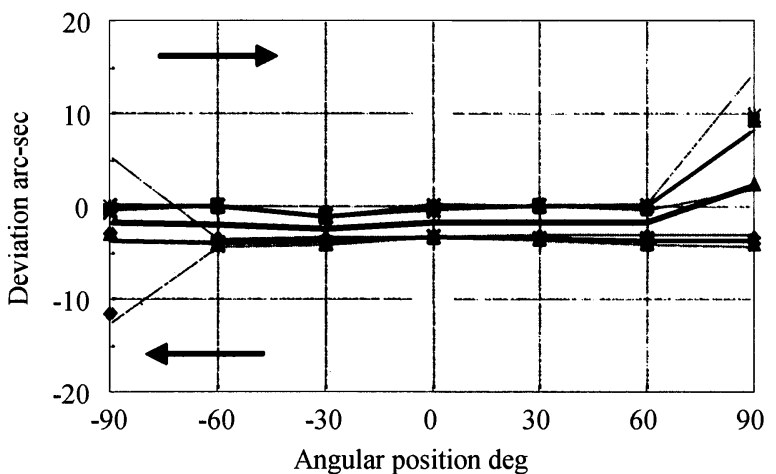

(a) Positioning deviations

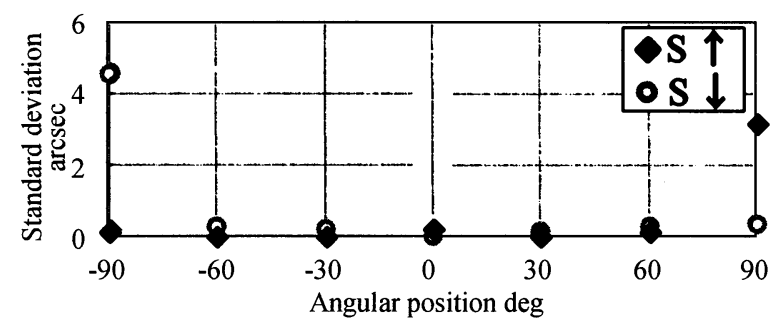

(b) Standard deviations

Fig. 14 Angular positioning deviations measured by the rotary encoder for feedback

標準偏差が 1”以下の精度で測定できる. 測定時間は気泡 管式水準器を使った場合に比べて短い.

以上の結果をもとに, 振子を自動的に調整し, かつ, 測定時 間を短縮するためにアクチュエータを利用した傾斜計を開発 する予定である.

\section{謝 辞}

本研究は, マザック財団の研究助成金を受けて行ったものの 一部である，関係各位に感謝の意を表す。

\section{考 文 献}

1）斉藤 明徳，宮川 元成，堤 正臣，同時 4 軸制御による 5 軸制 御マシニングセンタの位置偏差及び幾何偏差推定方法, 精密 工学会誌, 67, 2(2001) 306.

2）坂本 重彦, 稲崎 一郎, ボールバーによる 5 軸制御マシニング センタの組立誤差同定・評価法, 日本機械学会第 3 回生産加 工・工作機械部門講演会講演論文集，（2001） 157.

3）垣野 義昭, 井原 之敏, 佐藤 浩毅, 大坪寿, $\mathrm{NC} 工$ 工作機械の 運動制度に関する研究 (第 7 報) -DBB 法による 5 軸制御工作 機械の運動精度の測定-, 精密工学会誌，60，5（1994） 718.

4） JIS B 6192 : 工作機械一数値制御による位置決め精度試験方 法通則，日本規格協会，(1999）。

5）松丸 誠一, 工作機械の位置決め精度の現状 -上 機械と工具 (2003) 76.

6）松丸 誠一, 工作機械の位置決め精度の現状 -下 機械と工具 (2003) 98

7）アジレントテクノロジー(株)ホームページ http://cp.literature.agilent.com/litweb/pdf/5968-0111J.pdf

8） テーラーボブソン光学機器総合カタログ,テーラーホブソン株 式会社, (2005).

9）呉 淵宅, 回転体の回転角度測定装置及び測定方法, 公開特許 公報, 特願 2000-222959.

10）佐藤 隆太, 横堀 祐也, 堤 正臣，5 軸制御マシニングセンタ における直進軸之旋回軸の動的同期精度, 精密工学会誌, 72, 1 (2006) 73. 